\title{
Explaining Michael Lewis: Literary Form and Behavioral Economics in The Undoing Project (2017)
}

\begin{abstract}
:
This essay is concerned with the literary dimensions of Michael Lewis's The Undoing Project (2016), a journalistic depiction of the famous intellectual collaboration of Amos Tversky and Daniel Kahneman. Tversky and Kahneman are the Israeli psychologists whose work provided a new theoretical understructure for what is now called "behavioral economics," which has challenged norms of thinking that have longed presumed that consumer or business markets perform based on individuals' rational assessment of their own self-interest. The current public perception of Lewis is to see him as the master of the so-called explainer, the newswriting mode that supposedly draws from the Anglo-American journalistic traditions of realism and "plain speaking" transparency; the explainer itself has become more prominent across media platforms (e.g. in podcasts) in the U.S. in recent decades. However, what this interpretation of Lewis's writing overlooks, in the case of the Undoing Project, is the polyglot assemblage of literary and cultural debts Lewis mobilizes - from Charles Dickens and Mark Twain, American vaudeville and Yiddish humor, Voltaire and romantic comedy - to plot his explainer in the form of a love story. Through this literary strategy, moreover, Lewis tries to self-reflexively incorporate the theories behind behavioral economics into his own storytelling. In doing so, however, Lewis also confronts the ambiguous role that those theories play in contemporary history and, especially, U.S. political governance.
\end{abstract}

Keywords:

Michael Lewis, explanatory journalism, behavioral economics, narrative, romance

\section{Resumo:}

Este artigo foca-se nas dimensões literárias da obra de Michael Lewis The Undoing Project (2017), o retrato jornalístico da famosa colaboração intelectual entre Amos Tversky e Daniel Kahneman. Tversky e Kahneman são os psicólogos israelitas cuja investigação permitiu uma nova sub-estrutura teórica para o que hoje se designa como "economia comportamental", a qual veio desafiar normas de pensamento presumindo que os mercados actuam com base na avaliação racional que cada indivíduo faz do seu próprio interesse. 
Presentemente, Lewis é entendido pelo público como um dos mestres do denominado explainer, uma forma jornalística supostamente derivada das tradições jornalíticas anglo-americanas realistas e do falar de maneira transparente. Nas últimas décadas, o explainer tem-se tornado mais disseminado em plataformas noticiosas como os podcasts, sobretudo nos Estados Unidos. Contudo, o que esta interpretação de Lewis deixa de fora, mormente no caso de The Undoing Project, é a composição poliglota de endividamentos literários e culturais mobilizada por Lewis - desde Charles Dickens a Mark Twain, do vaudeville norte-americano ao humor Yiddish, de Voltaire à comédia romântica - a fim de compor o seu explainer à laia de uma história de amor. Através desta estratégia literária, Lewis tenta incorporar, auto-reflexivamente, as teorias subjacentes à economia comportamental na sua própria narrativa. Ao fazê-lo confronta, ademais, o papel ambíguo das mesmas na história contemporânea, particularmente na governança dos Estados Unidos.

Palavras-chave:

Michael Lewis, jornalismo explicativo, economia comportamental, narrativa, romance

One way to think of a book is as a series of decisions.

Michael Lewis

In recent years, the American long-form journalist Michael Lewis has established himself as one of the leading U.S. interpreters of all matters economic: of Wall Street panics, of the intersections between statistical "analytics" and professional sports, and - most recently of the wide influence of what has come to be known as behavioral economics. That is, in 2017, Lewis published The Undoing Project: A Friendship that Changed Our Minds, the story of Amos Tversky and Daniel Kahneman, the Israeli psychologists whose work provided a revolutionary theoretical understructure for how economists should think about market behavior, decisionmaking and forecasting of all kinds. As explained by economist Richard H. Thaler and legal scholar Cass H. Sunstein's Nudge: Improving Decisions about Health, Wealth, and Happiness (2008), behavioral economics has insisted that classical models of market activity - based, traditionally, on hypothetical individuals acting on their own rational self-interest - must begin to reflect instead how flawed, emotional, and sometimes irrational human beings actually behave. ${ }^{1}$ The Undoing Project in effect tells the personal backstory driving Tversky and Kahneman's research as it moves through an intense creative partnership that ends in dissolution and tragedy. Along the way, Lewis's book explicates the innovative ideas coming out of that intellectual partnership, and their influence on a wide array of fields: hospital care, hurricane prediction, political polling, stock market analysis, and much more.

In this way - to use the prominent term of the U.S. news trade - Lewis has once again been heralded as a leading practitioner of the journalistic genre known as the explainer, in 
his case the ability to elucidate, for popular audiences, what Michael Sandel has described as the "market triumphalism" of our day (2012: 6). In some quarters, Lewis has been called the "master explainer" of his generation (Turner; Smith). But Lewis takes things at least one step further than other American journalists one might nominate for this designation, such as Paul Solomon of the Public Broadcasting System (PBS), The New Yorker's Adam Davidson, or the peripatetic Malcolm Gladwell. What makes Lewis unique - and this is the central focus in what follows, below - is that he also speaks of having channeled this new economic thinking into his own identity as a writer. For instance, he says he prefers to forgo publishers' advance payments so that, like a lone entrepreneur, he alone will assume the risks of his books in the literary marketplace (Silver). Even more to the point, Lewis attempts to apply new economic theories to the literary techniques he uses in those books: to the logic behind his plots, to decisions about perspective and point of view, and even to the modes of explanation his writing puts in play. In one interview, he has described these ambitions by saying his work aims for "a kind of arbitrage," using a term that customarily refers to commodity exchanges across different markets (Silver). More simply put, as Lewis has it, if the theories we use to describe human decision-making are changing, say, in the fields of Psychology or Economics, then our literary modes of explanation must change as well.

In this essay, I want to explore these imaginative exchanges in The Undoing Project - that is, how Lewis applies Tversky and Kahneman's theories to his own account of them. Lewis's experiment is of a piece with any number of recent literary-journalistic attempts to rethink the narrative conventions commonly used to depict the disruptive, unpredictable, and inequitable conditions of modern market societies and the styles of political governance used to manage them. ${ }^{2}$ My exploration will therefore begin, in my first section, by briefly surveying the recent vogue of the journalistic explainer, and the aesthetic and political rationales commonly attributed to the mode. Largely, I will argue, the explainer has been folded into "plain-speech" and putatively democratic rationales that reflect official values of the mainstream U.S. news trade. Indeed, as my own essay's title means to suggest, Michael Lewis has been described in even more populist ways. Lewis is "explained," that is, as a writer who has mastered a nonfiction literary "formula" (Delistraty) that celebrates the common person, the so-called "little people" who stand up against those in power: a teenager who outduels the Securities and Exchange Commission, rogue stock analysts who outwit highly-paid brokerage houses, or a lone executive who defeats the "old guard" in professional baseball by coming up with new ways to evaluate his players' value. In books like Flash Boys (2014), Lewis is not above suggesting that U.S. economic markets are "rigged" in favor of the powerful, and thus in need of "radical change" (2014: 231-35).

Ultimately, however, this essay will challenge the populist image Lewis has been accorded. Such a revision begins, in my second section, with a fuller accounting of Lewis's own stylistic and aesthetic disposition, to use Pierre Bourdieu's term. Rather than simply working in a plain, expository style, Lewis draws on more literary, comic and satirical traditions both within American journalism and the performing arts more broadly. This orientation, in turn, made 
him all the more ready to cross-pollinate his writing with the disruptive theories of Tversky and Kahneman. In The Undoing Project specifically, this difference in disposition cuts in two directions. First, Lewis makes the quixotic decision to install Tversky and Kahneman's quite serious creative collaboration into the narrative architecture of a comic love story, and not only to draw out the covert emotional history between these two thinkers. And that's because, secondly, Lewis also wants to use behavioral economics to experiment - or, to use his own analogy for the imagination, to sport - with conventional modes of explanation and narration. Indeed, as I will show in my third section, this set of decisions leads Lewis into a self-reflexive meditation on the meaning of storytelling as such, not just in Economics or journalism but in the discipline of History as well.

In all, I mean to show that The Undoing Project is anything but a whimsical or formulaic exercise. Rather, Lewis's exploration introduces an important set of questions about the models of logic and explanation customarily used in U.S. long-form storytelling. Moreover, The Undoing Project has implications for how we understand important matters like health care, Wall Street regulation, and even the power of a figure like Donald Trump. On the other hand, Lewis's sporting with the politics of behavioral "nudging" reveal he is not quite ready to let go of the powers of storytelling he purports to lampoon. And Lewis's reputation aside, The Undoing Project is not quite the populist story it would seem.

\section{The Explainer}

In aesthetic terms, the journalistic explainer is probably better thought of as a mode than a genre (Zarzosa) since it is less a static formula than a flexible manner of presentation that traverses many different U.S. media platforms. Even the term explainer has long had eclectic meanings. It has been used in American print trades for everything from the old-standby nut graf, to the background article, to just about any long-form feature; the Pulitzer board has been awarding prizes for explanatory journalism since the mid-1980s. In some ways, the explainer is also a byproduct of the increasing emphasis on interpretive and story-based journalism in the U.S. news market in recent decades (Pauly; Schmidt). But the category has also been given a new look of late, as venues like the New York Times "Upshot" section, FiveThirtyEight, and Vox have drawn upon recent advances in graphic representation, Big Data, and data visualization. The explainer mode has become so pervasive that it occasionally takes on the status of a governing rationale - or, said differently, of an imperative to move content back and forth between print, online, and audio platforms. That Lewis's writing is so frequently singled out for its distinctive voice suggests its crossover value. On a podcast, in particular, the power of a given writer's voice is paramount. That is one reason why the label explainer has itself come to refer both to the mode in which a journalist writes and the persona that journalist's voice projects.

of course, the vogue of the explainer does have detractors. Where many embrace the category as quintessentially democratic in spirit, others deride its over-use as representing a need merely to aggregate information, much as if it were journalism's answer to Wikipedia or Google. Defenders, of course, respond that explainers help audiences make the news of 
more practical, personal use. The mode is commonly described as providing "nuanced" presentations of ongoing news stories, or as employing an "accessible," "colloquial" or "conversational" manner suitable for "more casual news consumers" mystified or put off by complex events. Explainers encourage readers, it is claimed, to revisit a headline story in more detail, engage it more substantively, and perhaps even change their mind (Zhang; Gaudette; Levenson; McDermott). In these ways, the explainer is thought of as a mode of re-reading, of slowing down the often-bewildering pace of the 24-hour news cycle. As The New Yorker's Adam Davidson has put it, the idea is to " "[give] people a way to sit" " for a while with the news, listen to someone who says, "'we can figure it out. We can understand it"” (Seward).

In a moment when the news media has been so frequently under attack, the goals of the explainer might therefore seem unobjectionable, at first. Nevertheless, as well-intentioned as these claims may be-and we should not forget that ideas about "balance" are rightly under scrutiny in a time of racial reckoning in the U.S. (Lowery) - such general norms do little to delineate the explainer's everyday literary operations, let alone the resolutely contrarian work of Michael Lewis. Indeed, these norms can sometimes result in a derogation of the very writers they mean to praise. Even when book-length explainers are celebrated, that is, they can be implicitly relegated to the lower or more nebulous echelons of nonfiction hierarchies: to what in the U.S. is called "popular science," to the long-neglected field of business journalism, or to the vaguest category of all, General Nonfiction. As a reviewer in the Los Angeles Times seems to have noticed, for example, The Undoing Project's back cover label tells booksellers to place it in store displays devoted to SCIENCE, while some online marketers even suggested it might also appear under SELF-HELP (Delistraty). Meanwhile, reviewers tend to treat style in nonfiction as an afterthought, or at its best when it does not distract from content (Wilson 2017). The default setting for long-form journalism is to see it merely as a collection or reorganization of facts, its content largely separate from form (e.g. Pitzer; contrast Frus). At most, as Susan L. Greenberg has recently noted, works of narrative journalism are praised under the catchall generality of "reading like a novel." Such ways of thinking about the explainer, again while well intentioned, can actually inoculate the mode from more serious critical analysis. In historical terms, these default settings can also cause us to give undue prominence to the supposedly "plain speech" (cf. Bennett) and "pragmatist" spirit said to reside within U.S. traditions of long-form journalism (see, for instance, Boynton 2005: xxi and ff.). Beyond the American exceptionalism encoded into such historical characterizations, they leave little room for exploring literary cross-pollination of the kind The Undoing Project represents.

Norms of transparency or realism can also cause reviewers of an explainer to conflate a book's objectives with its author's prior reputation, or to read its voice as simply that of the person behind the persona. Because Lewis wrote his first book, Liar's Poker (1989), about his apprenticeship in a brokerage house, many interpreters approach him as an expert on finance, despite his protestations to the contrary; ${ }^{3}$ conversely, reviewers overlook his college major in Art History, with its imperatives of decision-making about perspective, re-drafting, and so on. Because he is wont to mock himself as a goy with an Ivy League degree, Lewis often has to stop 
interviewers in their tracks, and remind them that he was also schooled at a historically Jewish academy (High) - training quite relevant to The Undoing Project. Perhaps because he can charm with a Southern drawl that seems native to his birthplace of New Orleans, we may overlook how truly performative his narrative voice can be. For instance, like the writer he confesses to admiring most, Tom Wolfe (Boynton 2005: 267-68), Lewis can throw his literary voice into the speech patterns of different characters, sporting with their vocabularies and thus disguising his own. Or, because we are taught not to judge a book by its cover, we can overlook the fact that Lewis's dust jacket for The Undoing Project actually has the optical illusion of a moving eraser positioned just above its boldly printed title. If is as if the writer has just expunged one name for his book, and drafted a new one. That eraser, importantly, is also a tool Lewis noticed on the desk of one of his explainer's heroes, Daniel Kahneman (2017: 116).

\section{The Literary Form(s) of The Undoing Project}

In some aspects, The Undoing Project can certainly "read like a novel." That is, after an introductory first chapter, the book's narrative subordinates its explanations of behavioral psychology and economic theory to the storyline of Amos Tversky's and Daniel Kahneman's childhoods, early academic careers, and creative partnership. The plot can also seem quite familiar to a frequent reader of novels: here, two seemingly antithetical characters, brought together by a matchmaking friend, become hopelessly attached to each other. Before long, they begin to shock their elders with their rebellious ideas and behavior - and yet, it all leads to what seems like an inevitable breakup, followed by the tragic sense that each figure will never shine as brilliantly again as when the two were together. (Many would later call Tversky and Kahneman the John Lennon and Paul McCartney of behavioral economics). Indeed, by crossing back and forth between the personal relationship of its central duo and the work they created, Lewis's book follows a strategy common to many a Victorian-era, Anglo-American social realist novel, in that its retrospective narrator relates two plots counterpointing love in the private sphere and "business" in the public one. Not surprisingly, then, when Lewis has spoken of more classical novelists with whom he identifies, he expresses an admiration for Charles Dickens (Boynton 2005: 267, 269). Dickens, of course, is famous for such interweaving, and for emphasizing that human desire and economic ambition often run afoul of events we cannot foresee (Dickens 2016: 73). To many literary historians, this counterpointing of the public realm of capitalism and the demands of bourgeois private life was the central business of the realist novel in the nineteenth century. One also thinks, for instance, of the U.S. realist William Dean Howells, whose The Rise of Silas Lapham (1885) arbitrages marriage and capitalism by punning on the difficulties of finding and keeping a "partner" in both realms. Howells's novel likewise uses art-historical words like "values" and "perspective" to investigate the ethical boundaries of each sphere and, like Dickens, to exhibit the costs of an unstable world where personal ruin could lead to economic catastrophe and vice versa (Crowley).

However-and here is our first indicator of the influence of behavioral economics on Lewis's literary thinking - to approach The Undoing Project solely in terms of these prior 
antecedents in the novel has significant limitations. So, too, would it be reductive to read Lewis's book exclusively in the journalistic norms attached to the "explainer" discussed earlier. In either case, to do so would be to fall victim to what Tversky and Kahneman call the "availability" heuristic, the mistake of resorting to a readily available mental "prototype" that only leads to confirmation bias (40), and thus a failure to see what's in front of you.4 For example, Lewis's very first chapter-opening with the taste- and gender-bending title of "Man Boobs" (21) - illustrates how this older way of thinking long haunted the evaluation of college players about to enter the market controlled by the National Basketball Association (NBA). Until quite recently, Lewis tells us, NBA scouts evaluated a player partly on the basis of how his body type matched up with those of basketball stars of the past. If a particular draftee did not match the prototype, scouts downgraded his future potential and avoided drafting him (40-45). As a result, these evaluators not only ended up simply reinforcing their attachment to the (outdated) mental prototype they had begun with; they also undervalued outside-thebox physical types who would, in some cases, go on to become All-Stars and by some lights change the game. In general, then, these scouts fell for what Lewis calls perhaps the "mind's best trick" (42): the illusion of certainty about their prior way of thinking. (Lewis's epigraph to The Undoing Project is from Voltaire, in translation: "Doubt is an uncomfortable condition, but certainty is a ridiculous one.")

In narrative terms, what all of the above illustrates is an observation Fredric Jameson once made about literary genres: that such prototypes are less "pure" manifestations of an ideal type than an "intersection" of several at once (322). The Undoing Project's canvas is itself best described as a polyglot composition suffusing its facts and explanations with the spirit of inquisitive uncertainty and touches of comic romance. Accordingly, the book's form comports with a digressive, recursive style of re-thinking more akin to the classical European and American essay than a well-ordered fiction. As in that essay tradition, formal, academic ideas are tested against random personal experiences; the amateur's uncertainty is embraced, put in the foreground ahead of orthodox truths. In addition, while The Undoing Project of course includes explanatory passages in the familiar journalistic sense, Lewis just as typically supplements them with a more comic, disruptive change of course that turns serious business into something closer to pratfall. Significant in this regard, in fact, is that he has also been known to speak fondly of the rambling, burlesque humor of Mark Twain (Boynton 267). Twain, of course, is also well known - here, a kinship with Voltaire is evident - for casting the fluid unpredictability of experience as the necessary corrective to naïve certainty, pride, and selfdelusion. When reminded that a cat would not sit on a hot stove twice, Twain replied that it wouldn't sit on a cold one, either (Twain 1908). A century before the invention of the podcast, Twain achieved wide popularity upon a literal platform (a stage) by crafting a populist voice that sometimes erratically changed its compositional course, as if on a whim. ${ }^{6}$

Appropriately, then, for the love story of Tversky and Kahneman, Lewis also does not draw upon prototypes of noble chivalry or epic quests for his romantic inspiration. Rather, he tends to favor vernacular, even lowbrow variants of comedic storytelling. His spirit connects, as did 
Twain's, to comedy in the sense of fatal misrecognitions, unexpected reversals, and upending chaos. At times Lewis even exhibits, we might say, an anarchic Marx Brothers spirit more than a Marxian one. A Yiddish joke is shared in The Undoing Project that in fact encapsulates its entire story: a burlesque dialogue where a matchmaker keeps making more extravagant claims about a potential bride until the bachelor finally agrees to meet her. When he does agree, though, the matchmaker says: "Good, we have half a match!" (279). This is a joke, moreover, displaying what Tversky and Kahneman call the fallacy of "transitivity" (103-108): the idea that a gobetween could possibly bring unlike spirits together simply because he or she likes either or both of them. As that slightly ribald chapter title "Man Boobs" suggests, Lewis sometime displays a distinct preference for this variety of boyish, roughhouse humor that lampoons conventional explanations and mocks "elders" and supposed experts. Turning back time by using first names for his main characters, Lewis describes "Amos" and "Danny" as reverting to the freedom of childhood. Lewis even suggests they turn their work into something like childhood play (181), a rebellion in disciplines where amateurs like themselves don't belong.7 Danny is said to feel that working with Amos is like being a kid left alone with the world's best toy closet at his disposal (181).

As this playfulness transforms into a deeper connection, Lewis correspondingly begins to mix in plot templates akin to Shakespeare's Taming of the Shrew or Hollywood movies like Pat and Mike. His two lead characters, though possessing completely different personalities, are inexplicably drawn to each other emotionally (though not sexually, Lewis insists). It's a surprising courtship. Though both Tversky and Kahneman had similar backgrounds as Jewish refugees, they had developed into completely different boys: as a child, Danny keeps his distance from others (66), while Amos becomes reckless, impulsive, and opinionated (90, 97). Initially, Lewis contrasts his heroes in summaries that read partly like Elizabethan foiling and partly like rapid-fire "treatments" for a Hollywood script:

Danny was always sure he was wrong. Amos was always sure he was right. Amos was the life of every party; Danny didn't go to the parties. Amos was loose and informal; even when he made a stab at informality, Danny felt as if he had descended from some formal place. With Amos you always just picked up where you left off, no matter how long it had been since you last saw him. With Danny there was always a sense you were starting over, even if you had been with him just yesterday. (155)

These radical differences are also reflected in their work spaces: on Danny's desk, pieces of paper are strewn everywhere, books are left open at pages where he has stopped reading; on Amos's, there is a complete absence of clutter, maybe a pencil on the desk, that's it (156-57). Danny is forever anxious, questioning, looking over his shoulder in muddled, inward silences; he is "moody-always in doubt" (128). Amos's defining characteristic, Lewis tells us, is his penchant for elaborate, engaging storytelling and humor. Using this premise of contrast, Lewis even mixes in a likeness to radio comedy and screwball films (which in some cases, of 
course, drew upon vaudeville and Jewish theatre). If the byplay of "Amos and Danny" reminds one of comedians like, say, "Amos 'n Andy," a colleague says this about Daniel Kahneman: that he was "like Woody Allen" but "without the humor" (129). By contrast, one day Amos decides to take up running. He strips down to his underwear and just darts out the door (97), much like Groucho Marx on the lam.

In time, however, these contrasting identities converge towards an even deeper interdependence. Especially in a chapter aptly entitled "The Collision" (142), the formerly antithetical thinkers now fall together so completely that each begins to take on the other's personality. As the two begin to work together, for example, Danny reciprocally inherits Amos's sense of humor, and his sense of folly or farce: statistical drudgery and doubt blends with a love of human folly. Recalling the laughter that was now constantly coming out of Amos and Danny's office (158), friends say it is almost as if the two would merge into a single physical form when together $(182,262)$. But perhaps most tellingly, the budding relationship makes them each want to be the persons that they are when they are alone with each other (181). As in many a romance, the bond between Danny and Amos becomes all-consuming: it takes over their work relationship and blocks out everything outside of it. ${ }^{8}$

\section{Undoing Explanations, Rewriting History}

At first, the comic effects I have described above might seem designed by Lewis merely to entertain his readers. And as I have said, Lewis is indeed interested in capturing his subjects' idiosyncratic personalities, and thus how Tversky and Kahneman's temperaments led them to theorize the role of chance and accident in decision-making and prediction. However, The Undoing Project does not stop there. Rather, as I have said, Lewis is also interested in how behavioral economics' focus on irrationality and bias - on distortions created by hindsight, by an over-reliance on common sense explanations, by prototypical thinking, and so on - might also be applied to his own literary decision-making. Consequently, Lewis begins to sport with the implications of Tversky and Kahneman's thinking for what one might call his own "economies" of explanation: for instance, for the decisions made by assigning meaning to particular past events, by delineating personalities, or by allotting justice or emotional rewards within his plot. ${ }^{9}$ Moreover, this meta-literary effect not only suffuses Lewis's approach to his own tools of narration; it also spirals out to his consideration the field of History, the discipline with "story" in its very name. His explanation of the history of Tversky and Kahneman's partnership thus doubles back on itself, and a book about economic theory becomes, in the end, a meditation on storytelling. ${ }^{10}$

The undoing of conventional narrative devices begins with Lewis's implicit interrogation of figurative comparisons such as metaphors or similes. Such comparisons, of course, typically establish the core devices of narrative structure that we call, for instance, parallelism or dramatic irony. Journalistic explainers themselves often work by figurative analogy - that is, by using a familiar subject to explain a complex one. A writer might use chess to explain military strategy; likewise we might refer, as Danny and Amos's friends do, to the mysterious 
"chemistry" of love (154), or say that their work relationship becomes "like" a marriage partnership, as Howells does. Figurative parallelism or elaborate conceits also allow a narrator to comment on interwoven plots, thereby enhancing explanatory authority. However, as Lewis tells it, Tversky and Kahneman have challenged the power of such figurative comparisons as explanatory tools. For instance, the two often disparaged what they called the fallacy of creating false "symmetry" (111-112) by resorting to "just a metaphor" (148) that actually explains very little. (What does chemistry actually explain about love, except that it can't be explained?) To Lewis's pair, a metaphor or a simile is a "cover-up" (316) for sloppy thinking, often so "uni-directional" (112) that it doesn't really amount to expressing meaningful similarity. For instance, Lewis explains, we can say love is as deep as an ocean. But in the obverse, it makes little sense to say oceans are as deep as love (112). Thus, as Lewis's own story advances, his tropes start to take on a centripetal instability, nearly erasing the implied parallels he's been previously sketching. For example, when Danny and Amos's relationship runs into trouble, Lewis writes that even before the two men had "left their marriages and married each other [...] it took no time at all for Danny to engage" someone else"s ideas (136-37, my emphasis). Elsewhere, however, Lewis calls their collaboration a "private affair" (289); when that affair frays, Danny's new collaborator says "'I thought they had agreed to see other people" (309). For Lewis, it seems, the marriage metaphor works until it doesn't.

Meanwhile, this attenuation of figurative comparisons carries over into Lewis's occasional undoing of retrospective narration as a tool of explanatory coherence. In realist fiction, again, novelists commonly create the illusion of a seamless world by installing narrators who are given the power to look back in time and make even minor events seem significant. As Elizabeth Deeds Ermarth and Amy Kaplan have argued, for instance, British and American novelists of the Victorian era commonly evoked an aura of social consensus by creating an internal economy of parallel plots that implicitly connected different social orders: elites to commoners, upstairs to downstairs, and so on. Victorian narrators often used characters' backstories, as Lewis does, to fill in the past and make the novel's created world seem rational and legible. Remember, however, that on Danny's desk, we see that inspiration for Lewis's own jacket cover: that eraser (116). When Lewis discusses his own main characters' childhoods, he actually sows doubt about both their meaning and, at times, their factuality. Instead, he suggests that his own rendering could be simply a product of rationalizing hindsight, as Tversky and Kahneman would say it is. For example: if, as we've been told, doubt is Danny's defining trait (52), it follows that he should have doubts about his own memories, or (if you think about it) the truth of the events that supposedly made him such a doubter. Much as if he is indeed making a humorless Woody Allen movie, Danny tracks down his memories and finds them distorted and implausible (59). ${ }^{11}$ Kahneman even comes to think that events he had long thought were formative have simply been selected in hindsight. "'People say your childhood is a big influence on who you become,' [Danny would] say, when pressed. 'I'm not at all sure that's true'" (61). Amos, similarly, says that how one chooses a professional partner or a romantic one is more accidental than rational: "[w]hich field we go into may depend on 
which high school teacher we happen to meet. Who we marry may depend on who happens to be around at the right time of life" (101). To these theorists, the result of past decisions only looks to have been inevitable because we know how things turned out.

The next step for Lewis is to take special interest in the moment when Tversky and Kahneman bring their thinking about hindsight to the discipline whose domain is the past: that of History. Tversky's goal, in particular, is to debunk historians' tendency - this is Lewis's paraphrase, I should add, not mine - "to take whatever facts they observed (neglecting the many facts that they did not or could not observe) and make them fit into a neatly confidentsounding story" (207). In other words, just as individuals will tend to use hindsight when they explain who they became on the basis of how they remember themselves as children, formal disciplines like History also reflect humans' "powerful instinct [...] for finding causes for any effect, and also for creating narratives" about the past (note, 66). Just like Economics, however, History needed a greater appreciation of uncertainty, Tversky says; just as we need to recognize that decision-making in markets looks "rational" only in retrospect, professionals who write about the past must also be wary of their tendency to eliminate randomness and chance in their stories. In one remarkable paraphrase of Tversky and Kahneman's own debunking spirit, Lewis suggests that the events from the past that we are liable to memorialize are actually the ones that can make us the most error-prone in the future. In this rather extreme casting, the entire premise of analyzing historical events - and thus, to create what is sometimes called a "usable" past - might well be undermined. For example, Lewis says that Amos and Danny end up re-composing George Santayana's famous dictum that "[ $t$ ]hose who cannot remember the past are bound to repeat it" (194). The new rule Tversky and Kahneman develop, Lewis writes, is now more like "He who sees the past as surprise-free is bound to have a future full of surprises" (208).

Indeed, as if to close the deal, Lewis seems to have had this revisionary maxim in mind when he wrote the finale of The Undoing Project itself. For it turns out that the future did have its own surprises in store for his two protagonists. Once "inevitable," the partnership of Tversky and Kahneman now comes to an end; Danny, in particular, seems increasingly intent on heading out on his own. Comparing their fraying personal relationship to the hubris of Wall Street investors, Lewis observes that "[t]hey'd thought they were rising when in fact they were falling" (298), and soon Amos and Danny part ways. Adding tragedy to the breakup, meanwhile, is the random event of Tversky's death from metastatic melanoma, not long after they've decided to go their separate ways. Recounting these events as he nears the end of his book, Lewis's own mood shifts from comedy to one of tragedy and regret.

That change in mood, however, does not mean that Lewis abandons his attempt to infuse his own story of the past with uncertainty. It might even be that Lewis's ultimate title for his book - the one, we imagine, he arrived at after erasing a few others - is itself unsettled by the tragic and yet chance ways that Tversky and Kahneman's partnership ended. For much of his book, as I've tried to demonstrate above, the title of The Undoing Project would seem to refer to the core value of that partnership - or, to put it in Lewis's terms, these two psychologists' 
shared love of undoing customary modes of explanation. At the book's end, however, we learn that the phrase "undoing project" also refers to a new experiment Kahneman has taken up on his own: to explain how and why people wish to go back into the past and try to imaginatively undo an event that has already happened. (A project that comes to suffuse Danny's own regrets about Amos.) In other words, here again a way of reading with a previous prototype in mind - specifically, the way we're commonly inclined to use a writer's book title to capture a text's overarching meaning - becomes more uncertain. After all, Lewis's own title could also refer to Danny's solitary vigil, or to the unfinished business, work-related and emotional, that both he and Amos had left between them.

\section{The Risks of Romancing Behavioral Economics}

Nevertheless, at the end of The Undoing Project, we ourselves are liable to be left with some unresolved questions about Lewis's own love affair with behavioral economics. For one thing, maintaining the spirit of "undoing" seems to run contrary to Lewis's other desire, which is to emphasize the wide influence of Tversky and Kahneman's theories. In the book's denouement, for example, Lewis makes it seem that their joint achievement had even gotten in "under the bell" - the ringing telephone call (352) - that Danny receives congratulating him for his Nobel Prize, awarded to him individually after Amos's death. In other words, Lewis suggests Danny's shared achievement with Amos will live on beyond the latter's death. Rather than featuring an undoing mood, Lewis now seems to tie up loose ends in a more orthodox way. This motif of transcending the limits of the material world is in fact a familiar convention of closure in romance: though the star-crossed lovers cannot share in the world they helped to make, the example of their bond lives on, even offering a model of peace-making between formerly warring parties. Love survives human constraint, strife, and fallibility (Cawelti 41-2). Even the pun in the final subtitle Lewis had decided upon - claiming that Tversky and Kahneman have "Changed Our Minds" - presents their revolt as having achieved their triumph together.

Among the many decisions Lewis made in writing his explainer, perhaps it is unfair to question this one. It may be that, by invoking a supposedly arrived-at consensus, Lewis meant to enlist the reader one more time in his rebels' cause. As the author revealed in subsequent interviews, Tversky's death had even threatened the completion of this very book (High). Nevertheless, Lewis's choice to end the way he did again points to tensions between behavioral-economic thinking and the desire to deploy comedic or romance forms to explain it. Indeed, we might say that Lewis's own obvious affection for his subjects doesn't come without costs. Lewis does not turn, for example, to a critical examination of the results that behaviorist theories have had; nor does he delve deeply into whether such changes are socially beneficial and if so, to whom. Rather, he seems content to invoke an air of hubris: Tversky and Kahneman's work is portrayed as having cornered the market on what "our" minds supposedly all believe.

Furthermore, Lewis's discussion of the limitations of History writing cannot paper over the fact that Lewis has been writing one, himself. We might therefore look back and speculate 
about what might have been left out of his account. Romances have a way of being a bit too enclosed within the world of the lovers they foreground, and Lewis's is no exception. George Packer's history of the contemporary era, for example, demonstrates that foundational forms of social cohesion and political authority in the U.S. had already been eroding - Packer's word is Unwinding, not Undoing - well before Tversky and Kahneman stormed what Lewis depicts as supposedly secure bastions of power. Packer thus creates a quite different picture of what had already been disrupted, by whom, and to what ends. Often restricting the reader's perspective to Tversky and Kahneman's rebellion, The Undoing Project's view of the expert authorities they have challenged can also seem a bit one-sided and even ungenerous. Despite the Panglossian blindness that the book attributes to professional historians, for instance, they have long recognized the risks of hindsight (Novick). Meanwhile, Lewis rarely considers disciplinary envy as part of his rebels' motivation. Instead, he seems to embrace Tversky and Kahneman's desire to clear the decks of History, as if the Invisible Hand of their theories has grabbed the Great Eraser, and "we" must all start over.

Other problems with this populist cover story arise when The Undoing Project discusses how Tversky and Kahneman's critique of the human propensity for storytelling might actually be applied. Throughout much of the book, as I have tried to show, Lewis seems to relish his duo's questioning of storytelling as an explanatory and persuasive tool. However, especially as Lewis's book moves into its final third, he can just as often be found praising those who are currently re-deploying the power of storytelling rather than working to discount it. Once someone has absorbed the principles of behavioral economics, it seems, Lewis worries less about the potentially manipulative aspect of their new stories. For example, he offers largely approving anecdotes about doctors who have now learned to re-frame the odds for patients facing surgery (226), Wall Street brokerage houses who re-craft their advice for traders and clients (275-76), and so on. Most strikingly, this more positive casting of storytelling permeates Lewis's treatment of Cass Sunstein's work for the Obama administration (see Vinick). Obviously drawn to the vocabulary of Thaler and Sunstein's own book about behavioral economics, Lewis praises those who design a "choice architecture" to "nudge" people to select government programs that offer what is supposedly best for them. Lewis likewise gives Thaler an especially heroic story of having overcome a stern father who had cruelly forced his dyslexic son to transcribe, over and over, pages from Twain's The Adventures of Tom Sawyer (279). Thaler nevertheless rose above this background, Lewis tells us, eventually to garner a Nobel Prize, while his book with Sunstein established a foothold for behavioral economics in Obama's Presidency. There Sunstein practices what Nudge calls a "libertarian paternalism" (5) because, even though it attempts to push citizens towards certain outcomes, it always preserves an element of choice by offering some of them an opt-out.

This particular application, however, only betrays the limits of Lewis's supposed populism. Of course, whether Thaler and Sunstein's political platform is or isn't what they say it is - particularly whether it's really democratic in spirit - reflects a debate as old as liberalism itself. As we know from Obamacare, for instance, an "opt out" is usually available 
only to those who can afford to pay for it. But in my view this glowing treatment of Sunstein and Thaler's views exposes a fundamental tension within Lewis's casting of behavioristinspired governance. As writers such as Packer and Anand Giridharadas have recently argued, for example, the allure of such "light touch" governance to political leaders is that it offers to circumvent, but thereby leave untouched, more fundamental structures that have produced economic and political inequality in the first place. In other words, since Lewis's description of Thaler and Sunstein describes rather technocratic, top-down approaches, we might legitimately wonder how populist his own worldview really is. As Tamsin Shaw has written, Lewis's treatment of Tversky and Kahneman's theories can also seem rather antiseptically sealed off from the notoriously "nudging" power of advertising and political propaganda. After all, some of the most daunting forces facing today's democracies are themselves seizing the power of storytelling for less-than-altruistic purposes. Immediately following the publication of The Undoing Project, for example, Lewis was asked to comment on his book's implications for the rise of Donald Trump. Lewis responded by saying that Trump simply represented the desire to return to a supposedly secure American past; the journalist therefore placed Trump in the camp of certainty to which he himself was, obviously, opposed (Silver). But to put it mildly, Lewis did not seem to account for the fact that Trump and his circle had also been using storytelling with the intention of sowing doubt - and with the effect of enhancing inequality and social division, not reducing them. Even Lewis's brief allusion to Tom Sawyer unwittingly references perhaps that novel's most ambiguous story: the one about the sheer hucksterism of Tom Sawyer conning his boyhood chums to paint a fence so he doesn't have to.

All of the above is not meant to dismiss The Undoing Project's contributions to our understanding of journalistic explainers and narrative journalism generally. Lewis's polyglot, revisionary undoing of the default-setting realist protocols in U.S. nonfiction is especially suggestive. Making an explainer simply "read like a (realist) novel" can often mean blocking out the uncertainties surrounding any event, creating the illusion of unmediated witnessing, and giving hindsight the fallacious aura of omniscience. Nor is a warm or reassuring voice, in whatever form or media platform one chooses, any guarantee of authority or ideological neutrality: narrating is nudging, just as explanation is always interpretation. Explaining to whom also needs considering, especially since claiming to reach out to "casual" or "general" readers is often a way to avoid talking more specifically, and demographically, about who one's readers actually are. ${ }^{12}$ But in the end, it is the explainer's rhetorical attachment to populist or democratic values that needs vigilant questioning. In his best moments, Lewis has demonstrated an undisguised affection for outliers and common citizens who expose the corruption of the powerful; this surely can be one of the explainer's best uses. However, we could do worse than turn that populist spirit back against some of the mode's own assumptions, and ask who learns, or who benefits, from the disruptive changes it often describes. If we do, there will still be many worthwhile explainer projects out there, waiting to be written. Of that I am reasonably certain. 


\section{NOTES}

* Christopher P. Wilson is Professor of English (Emeritus) at Boston College. He is the author of four books on American literature and culture, including Cop Knowledge: Police Power and Cultural Narrative in 2oth Century America (2000) and Learning to Live with Crime: American Crime Narrative in the Neoconservative Turn (2010). Of late, he has published essays in Raritan, Twentieth-Century-Literature, MELUS, College Literature, Literary Journalism Studies (LJS) and The Journal of American Studies. He has served on editorial or advisory boards for American Quarterly, American Literature, and LJS. Most recently, he has created Reading Narrative Journalism, an introductory classroom text in the field, available at https://mediakron.bc.edu/ readingnarrativejournalism.

${ }^{1}$ This My epigraph from Lewis (2017: 362); all further citations in text. All quotations in this essay attributed to Tversky and Kahneman are also from Lewis (2017).

${ }^{2}$ See Wilson (2017) and (forthcoming).

${ }^{3}$ Lewis told Boynton (267) that he didn't think he had "anything in common with, say, a business reporter"; however, he added, "I have huge literary ambitions."

${ }^{4}$ Lewis's Moneyball (2003) elaborates on this point. See also Aitchison.

${ }^{5}$ For these conventions of the essay see Sontag (150).

${ }^{6}$ The best-known example of Twain's compositional impulsiveness is The Adventures of Huckleberry Finn. But Twain is famous for undoing the norms of nineteenth-century autobiography as well, in part by experimenting with early dictation technology (DeEulis).

${ }^{7}$ As is commonly observed, one root of the English word amateur is love. Cavell is perhaps best known for arguing that the education of an ingénue was often central to screwball comedy.

${ }^{8}$ One historian of courtship, Ellen Rothman (97), has described this as the "We are Not Like Most People" ethos that young lovers often share.

${ }_{9}$ On this kind of allotment in plotting, see especially Brooks, e.g. xii, 5, 11, 18.

${ }^{10}$ Lewis's titles - for instance, The Blind Side, or Boomerang - often point to these self-reflexive dimensions in his thinking. See also Senior.

${ }^{11}$ Nelson's incisive account of the journalist Mary McCarthy's use of memoir is quite relevant here (77-78).

${ }^{12}$ Citing market research, McDonnell (5) has written that 60 percent of U.S. book buyers are women, $61 \%$ are college educated, and $63 \%$ have an annual income of $\$ 50,000$ or more. 


\section{Works Cited}

Aitchison, Jean (1987), Words in the Mind: An Introduction to the Mental Lexicon. New York, Blackwell.

Bennett, Karen (2019), "Plain English: The Rhetoric of 'Anti-Rhetoric' and its Consequences for Anglophone Culture." English Studies, vol. 100, no. 6 (2019): 688-709. doi: 10.1080/0013838X.2019.1613104.

Bourdieu, Pierre (1993), The Field of Cultural Production: Essays on Art and Literature. New York, Columbia University Press.

Boynton, Robert S. (2005), The New New Journalism: Conversations with America's Best Nonfiction Writers on Their Craft. New York: Vintage Books.

Brooks, Peter (1984), Reading for the Plot: Design and Intention in Narrative. New York, A.A. Knopf.

Cavell, Stanley (1981), Pursuits of Happiness: The Hollywood Comedy of Remarriage. Cambridge, Harvard University Press.

Cawelti, John (1976), Adventure, Mystery, and Romance: Formula Stories as Art and Popular Culture. Chicago, University of Chicago Press.

Crowley, John (1983), "Howellsian realism: A psychological juggle." Studies in the Literary Imagination, vol. 16, no. 2 (1983): 45-55.

Delistraty, Cody (2016), "Michael Lewis and the nonfiction narrative formula." Los Angeles Times, 9 Dec. 2016 <https://lareviewofbooks.org/article/michael-lewis-narrativenonfiction-formula/>.

DeEulis, Marilyn (1981), "Mark Twain's Experiments in Autobiography." American Literature, vol. 53, no. 2 (1981): 200-213. doi:10.2307/2926099.

Dickens, Charles (2016), Hard Times: The Critical Edition, New York, 4th ed. New York: Norton.

Ermarth, Elizabeth (1983), Realism and Consensus in the English Novel. Princeton, Princeton University Press.

Frus, Phyllis (1994), The Politics and Poetics of Journalistic Narrative. New York, Cambridge University Press.

Gaudette, Emily (2019), "How the explainer changed digital media forever." Content Strategist, 23 January 2019. <https://contently.com/2019/01/23/explainer-changed-digitalmedia/>.

Giridharadas, Anand (2018), Winners Take All: The Elite Charade of Changing the World. New York, Knopf.

Greenberg, Susan L. (2020), "The Uses of Literary Journalism: From History to Future Directions." [Review of William E. Dow and Roberta S. Maguire, eds. The Routledge Companion to American Literary Journalism.] Literary Journalism Studies, vol. 12, no 2 (2020): 127-129.

Jameson, Fredric (1982), "Towards a New Awareness of Genre." Science Fiction Studies, vol. 9, no. 3 (1982): 322-324. https://www.jstor.org/stable/4239507. 
Kaplan, Amy (1988), The Social Construction of American Realism. Chicago, University of Chicago Press.

Kovach, Bill; Rosensteil, Tom (2001), The Elements of Journalism. New York, Crown Publishers. "S L." "The Economist explains the fashion for explainer articles." The Economist, 9 June 2014. < https://www.economist.com/the-economist-explains/2014/06/08/the-fashionfor-explainer-articles $>$.

Levenson, Eric (2014), "The New York Times enters the data/explainer journalism horse race." The Atlantic, 22 April 2014. <https://www.theatlantic.com/culture/archive/2014/04/thenew-york-times-enters-the-data-explainer-journalism-horse-race/361028/>.

Lewis, Michael (1989), Liar's Poker: Rising through the Wreckage on Wall Street. New York, Norton.

-- (2003), Moneyball: The Art of Winning an Unfair Game. New York, W.W. Norton.

-- (2006), The Blind Side: Evolution of a Game. New York, W.W. Norton.

- - (2010), The Big Short: Inside the Doomsday Machine. New York, W.W. Norton.

-- (2014), Flash Boys: A Wall Street Revolt. New York, W.W. Norton.

-- The Undoing Project: A Friendship That Changed Our Minds. New York: W.W. Norton, 2017.

Lowery, Wesley (2020), "A Reckoning over Objectivity, Led by Black Journalists." New York Times, 23 June 2020. <https://nyti.ms/319OucM>.

McDermott John (2014), "Explaining what's behind the sudden allure of explanatory journalism." Digiday, 17 March 2014. <http://projects.nyujournalism.org/ newsliteracy2016/topics/explainer-journalism/>.

McDonnell, Nic (2018), The Bodies in Person: An Account of Civilian Casualties in American Wars. New York, Blue Rider Press.

Nelson, Deborah (2017), Tough Enough: Arbus, Arendt, Didion, McCarthy, Sontag, Weil. Chicago, University of Chicago Press.

Novick, Peter (1988), That Noble Dream: The "Objectivity Question" and the American Historical Profession. Cambridge, Eng.: Cambridge University Press.

Packer, George (2013), The Unwinding: An Inner History of the New America. New York, Farrar, Straus \& Giroux.

Pat and Mike (1952), Directed by George Cukor, Metro-Goldwin-Mayer.

Pauly, John (2014), "The New Journalism and the Struggle for Interpretation." Journalism, vol. 15, no. 5 (2014): 589-604. doi:10.1177/1464884914529208.

Pitzer, Andrea (2010), "Nieman Storyboard conversation between Darcy Frey and Tracy Kidder." Nieman Storyboard, 21 Oct. 2010.

<https://niemanstoryboard.org/stories/tracy-kidder-narrative-nonfiction-darcy-freyharvard-writers-at-work-part-1/ > .

Rothman, Ellen (1984), Hands and Hearts: A History of Courtship in America. New York, Basic Books.

Sandel, Michael (2012), What Money Can't Buy. New York, Farrar, Strauss \& Giroux.

Schmidt, Thomas (2019), Rewriting the Newspaper: The Storytelling Movement in American Journalism. Columbia, University of Missouri Press. 
Cadernos de Literatura Comparada

Explaining Michael Lewis: Literary Form and Behavioral Economics in The Undoing Project (2017)

Senior, Jennifer (2016), "Review: Michael Lewis on two well-matched (but finally mismatched) men." New York Times, 1 Dec. 2016, <https://www.nytimes.com/2016/12/01/books/reviewmichael-lewis-on-two-well-matched-but-finally-mismatched-men.html > .

Seward Zachary M. (2009), "NPR's Adam Davidson explains the explainer: A model for Complex news." Nieman Lab, 31 March 2009, <https://www.niemanlab.org/2009/03/ nprs-adam-davidson-explains-the-explainer-a-model-for-complex-news/ >.

Shakespeare, William (2010), The Taming of the Shrew (1590-92). London, Arden Shakespeare; 3rd ed..

Shaw, Tamsin (2017), "Invisible manipulators of your mind." New York Review of Books, 20 April 2017, <https://www.nybooks.com/articles/2017/04/20/kahneman-tverskyinvisible-mind-manipulators/ $>$.

Silver, Nate (2016), "Nate Silver interviews Michael Lewis about his new book, 'The Undoing Project," " FiveThirtyEight.com, 16 Dec. 2016, <https://fivethirtyeight.com/features/natesilver-interviews-michael-lewis-about-his-new-book-the-undoing-project/>.

Smith, Kyle (2011), [Review of Boomerang], Forbes, 28 Sept. 2011, <https://www. forbes.com/sites/kylesmith/2011/09/28/book-review-boomerang-by-michaellewis/\#79f284e11ee2>.

Sontag, Susan (1992), [From the Introduction to The Best American Essays 1992], in Carl H. Klaus and Ned Stuckey-French (eds.), Essayists on the Essay: Montaigne to Our Time. Iowa City, University of Iowa Press, 147-152.

Thaler, Richard H.; Cass R. Sunstein (2008), Nudge: Improving Decisions about Health, Wealth, and Happiness. New York, Yale University Press.

Turner, Richard (2019), "Michael Lewis makes boring stuff interesting." Wall Street Journal, 17 May 2019, <https://www.wsj.com/articles/michael-lewis-makes-boring-stuffinteresting-11558098125>.

Twain, Mark (1985), The Adventures of Huckleberry Finn (1885). Berkeley, University of California Press.

-- (1908), Following the Equator: A Journey Around the World. Project Gutenberg, <https://www. gutenberg.org/files/2895/2895-h/2895-h.htm > Hartford, American Publishing Co..

-- (1903), The Adventures of Tom Sawyer (1876). New York, Harper \& Bros..

--; Vinik, Danny (2015), “Obama's Effort to 'Nudge' America." Politico, 15 Oct. 2015, https:// www.politico.com/agenda/story/2015/10/obamas-effort-to-nudge-america-000276/>.

Wilson, Christopher P. (2017), "The Chronicler: George Packer's The Unwinding (2013)." post45, https://post45.org/2017/05/the-chronicler-george-packers-the-unwinding-2013/.

-- (Forthcoming), "Markets and Players: Plotting Poverty and Citizenship in Matthew Desmond's Evicted." Forthcoming in The Journal of American Studies.

Zarzosa, Agustin (2010), "Melodrama and the Modes of the World." Discourse, vol. 32, no. 2 (2010): 326-255. Project MUSE muse.jhu.edu/article/426892.

Zhang, Quifan (2016), "Explaining the News Builds an Audience for It." News Literacy 2016, 28 Feb. 2016, <http://projects.nyujournalism.org/newsliteracy2016/topics/explainerjournalism/> 